\title{
Effect of a Gel Based on Ipomoea batatas (Purple Sweet Potato) on Dermal Wound Healing in Mice
}

\author{
Carmen R. Silva-Correa ${ }^{1, *}$, Cristel M. Ortiz-Noriega ${ }^{1}$, Víctor E. Villarreal-La Torre ${ }^{1}$, Abhel A. Calderón-Peña ${ }^{2}$, \\ Cinthya L. Aspajo-Villalaz², Luz M. Guerrero-Espino³, William A. Sagástegui-Guarniz', Anabel D. González- \\ Siccha', María V. González-Blas' ${ }^{1}$, José L. Cruzado-Razco', Jorge Del Rosario-Chávarri' ${ }^{2}$, Patricia Contreras- \\ Vera $^{4}$, Julio Hilario-Vargas ${ }^{3}$
}

Carmen R. Silva-Correa ${ }^{1, *}$, Cristel M. Ortiz-Noriega', Víctor E. Villarreal-

La Torre' ${ }^{1}$ Abhel A. Calderón-Peña², Cinthya L. Aspajo-Villalaz' ${ }^{2}$ Luz

M. Guerrero-Espino ${ }^{3}$, William

A. Sagástegui-Guarniz' ${ }^{1}$ Anabel

D. González-Siccha' ${ }^{1}$, María V.

González-Blas' , José L. Cruzado-

Razco', Jorge Del Rosario-

Chávarri², Patricia Contreras-Vera ${ }^{4}$, Julio Hilario-Vargas ${ }^{3}$

'Facultad de Farmacia y Bioquímica, Universidad Nacional de Trujillo, PERÚ.

${ }^{2}$ Facultad de Ciencias Biológicas, Universidad

Nacional de Trujillo, PERÚ.

${ }^{3}$ Facultad de Medicina, Universidad Nacional de Trujillo, PERÚ.

${ }^{4}$ Hospital Víctor Lazarte Echegaray, Trujillo, PERÚ.

\section{Correspondence}

Carmen R. Silva-Correa

Facultad de Farmacia y Bioquímica, Universidad Nacional de Trujillo, PERÚ.

E-mail: csilva@unitru.edu.pe

History

- Submission Date: 10-10-2021;

- Review completed: 11-11-2021.

- Accepted Date: 15-11-2021.

DOI : 10.5530/pj.2021.13.222

Article Available online

http://www.phcogj.com/v13/i6

\section{Copyright}

(C) 2021 Phcogj.Com. This is an openaccess article distributed under the terms of the Creative Commons Attribution 4.0 International license.

\section{ABSTRACT}

Background: Ipomoea batatas (L.) Lam. (I. batatas) is a root native from South America that is characterized by its antioxidant, antimicrobial and anti-inflammatory properties. These properties contribute to the wound healing process. Objective: To evaluate the healing activity of a gel based on I. batatas on dermal wound healing in mice. Material and methods: An acid ethanolic extract (1.5 N hydrochloric acid: Ethanol $96^{\circ} 15: 85, \mathrm{v} / \mathrm{v}$ ) was prepared with the peels of the roots of $I$. batatas "purple sweet potato", which was incorporated into the formulations $0.5 \%$ and $1 \%$ gel. Mus musculus Balb / c with induced injury were distributed in four experimental groups: Group I (Control), which did not receive any treatment. Group II (Gel base), Group III (Gel I. batatas $0.5 \%$ ) and Group IV (Gel I. batatas $1 \%$ ) received the daily administration of topical treatments for 14 days. Wound closure was determined during the experimentation time, then they were euthanized with sodium pentobarbital $60 \mathrm{mg} / \mathrm{kg} / \mathrm{pc}$ v.ip. to obtain skin samples for histopathological analysis. Results: Group IV shows a higher percentage of wound closure, which is also evidenced in histopathological changes. Conclusions: The $1 \%$ gel based on the ethanolic extract of the peels of the roots of Ipomoea batatas (L.) Lam. they show healing activity in wounds induced in mice, being the most effective treatment.

Key words: Ipomoea batatas, Wound healing, Histology, Skin.

\section{INTRODUCTION}

Wounds are one of the most common health problems worldwide and can be described as the deterioration of the structural and functional integrity of the epithelial tissue of the skin caused by a thermal, physical injury, or an underlying pathological condition. They can spread to other tissues and surrounding structures ${ }^{1-2}$ causing a series of cellular and molecular responses that allow the natural state of the skin to be restored. This process is known as healing ${ }^{3-4}$ and involves four different phases: hemostasis, inflammation, proliferation and ends with remodeling. ${ }^{5-6}$

Ipomoea batatas (L.) Lam. (I. batatas) known as sweet potato, is one of the most important food crops in the world. It is a dicotyledonous plant native to America with a herbaceous consistency that is grown annually. ${ }^{7}$ Its roots are the edible portion of the plant and they present a great variety of colors: white, yellow, orange, pink and purple. ${ }^{8}$ Sweet potatoes have been extensively investigated due to their high polyphenol content and the presence of anthocyanins. ${ }^{9-11}$ Also has a variety of biological activities, among which we can mention its antioxidant, ${ }^{12}$ hypoglycemic, ${ }^{13}$ antiinflammatory, ${ }^{14}$ neuroprotective, ${ }^{15}$ antibacterial, ${ }^{16}$ antiulcer ${ }^{17}$ and anticancer. ${ }^{18}$

Today, the treatment of skin lesions is a frequent problem and although on the market we find pharmaceutical products that promise safety and efficacy; all do not show the expected results. Given this, the goal of this study was to evaluate the healing activity of a gel based on Ipomoea batatas (L.) Lam. on induced wounds in mice.

\section{MATERIAL AND METHODS}

\section{Biological material}

Mus musculus Balb/c (35-40 g) male, 3 and a half months old were used for this investigation. Mice were kept in cages and standard environmental condition of photoperiod 12:12 hours (light / dark) with a temperature of $25 \pm 2^{\circ} \mathrm{C}$. They were given a balanced diet and water administered ad libitum. The study was approved by the Ethics Committee of the Facultad de Farmacia y Bioquímica - Universidad Nacional de Trujillo with the document COD. $\mathrm{N}^{\circ}$ : PR005-2021/CEIFYB

Vegetal material and Preparation of the extract

Roots of Ipomoea batatas (L.) Lam., were acquired in the District of Huanchaco, Province of Trujillo, Region La Libertad, Peru. The peels of the roots of Ipomoea batatas were washed, cut and placed in an extraction solution of $1.5 \mathrm{~N}$ hydrochloric acid and $96 \%$ ethanol $(15: 85, \mathrm{v} / \mathrm{v})$. The mixture obtained was macerated for 72 hours in an amber flask, with daily stirring, subsequent filtration and concentration in a rotary evaporator at $40^{\circ} \mathrm{C}$. The dry extract obtained was placed in an amber container and stored at $-20^{\circ} \mathrm{C}$.

\section{Preparation of the gels ${ }^{19}$}

The base gel formulation was prepared based on carbopol, liquid glycerin, propylene glycol, 
triethanolamine and water. To obtain the $0.5 \%$ and $1 \%$ gels, the extract was added to the base gel until the established concentration was obtained. Finally, the formulations were packaged, labeled and stored at room temperature until use.

\section{Evaluation of healing activity ${ }^{20}$}

Backs of all mice were depilated and wounds were induced within 48 hours. Anesthetic in $2 \%$ lidocaine cream was applied topically and a cut perpendicular to the longitudinal axis of the mouse of approximately 1 $\mathrm{cm}$ in length was made. The measurement was made with the help of a Vernier caliper.

20 mice were randomly distributed into 4 experimental groups with 5 specimens per group: Group I (Control), to which no treatment was applied, Group II (Base Gel), Group III (Gel I. batatas 0.5\%) and Group IV (Gel I. batatas 1\%). Groups II, III and IV received daily administration of topical treatments for 14 days using sterile swabs for their application. The wound healing process was recorded, evaluating wound closure throughout the treatment.

\section{Histopathological study ${ }^{20}$}

During euthanasia, all experimental animals were administered pentobarbital sodium $60 \mathrm{mg} / \mathrm{kg}$ v.ip. and skin samples were obtained by making a cut $1.5 \mathrm{~cm}$ long and $1 \mathrm{~cm}$ wide around the scar. The skin samples were preserved in sterile bottles with $10 \%$ formaldehyde solution to be histopathologically evaluated.

\section{Statistical analysis}

Data are expressed as mean \pm standard error of the mean (SEM) on a Bardot scatter plot and one-dimensional on a band plot. The graphs were prepared using R language (R-GUI v.4.1.0) performing an analysis of variance (ANOVA) followed by the post Hoc Tukey test. Values are considered statistically significant at $\mathrm{p}<0.05$.

\section{RESULTS}

\section{Determination of wound healing}

Wound closure is a parameter that determines the evolution of the healing process. Therefore, a comparison of wound healing was made in the experimental groups during the 14 days of treatments, which is shown in Figure 1. The wound closure percentages of Group II (Base Gel), Group III (Gel I. batatas 0.5\%) and Group IV (Gel I. batatas 1\%) show a significant difference compared to Group I (Control). At the same time, Group IV shows a significantly higher percentage of wound closure from day 6 post treatment $(\mathrm{p}<0.05)$. The evaluation of the treatment at day 10 shows that group IV completes the wound closure compared to group I (Control).

\section{Histopathological changes}

Figure 2 shows histopathological changes in mouse skin samples. In Group I (Control), no differentiation of basal cells is observed at the level of the epidermis, and connective tissue with few fibroblasts arranged in parallel is observed in the dermis. These findings correspond to a progressive and physiological scarring, but with the presence of inflammatory cells related to the effect of the induced injury. Group II, which received treatment with the base gel, does not show basal cell differentiation, which is an indication of re-epithelialization, and in the dermis the connective tissue is observed containing few fibroblasts and collagen fibers to fill and contract the wound.

Groups III and IV that received the topical formulations of I. batatas show greater healing activity. Group IV, which received the $1 \%$ gel treatment, shows continuity of re-epithelialization at the level of the epidermis. In the dermis, intense activity of the reparative wound healing phenomenon is observed due to the parallel arrangement of fibroblasts and abundant collagen due to the effect of gel treatment compared to the other experimental groups.

\section{DISCUSSION}

The results show that the topical administration of gel of I. batatas in a mouse wound model leads to a significant acceleration in wound healing, which was observed in the percentage of wound closure that occurred in less time in comparison to the control group. The faster healing time reduces the possibility of complications in the injury, these in turn reduce the costs that may be involved in prolonging the treatment. ${ }^{21}$

In the histopathological analysis of the groups that received the purple sweet potato gels, an active recovery of the stratum corneum, granular, spinous and basal cells is shown. These later will be in charge of replacing the dead epidermal cells. In the dermis there is abundant formation of fibroblasts arranged parallel to the epidermis. These histological data indicate an adequate healing process, mainly in group IV. It is also observed the formation of dermal papillae that play a crucial role in regulating the growth and cycle of hair follicles, due to the fact that they generate instructive signals to induce the proliferation of protruding epithelial cells, ${ }^{22}$ and induce new hair follicles and hair fibers. ${ }^{23}$

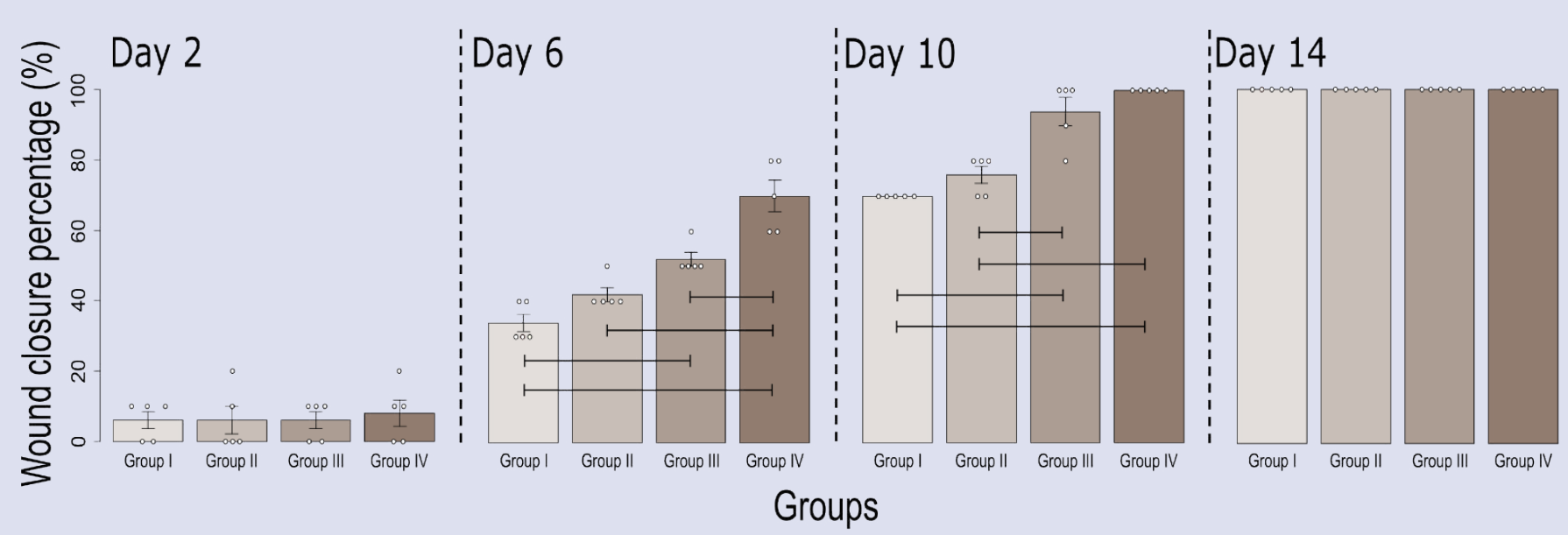

Figure 1. Percentage of wound closure in the experimental groups during the treatment days. Results expressed as mean \pm SEM in a Bardot and onedimensional scatter diagram in a stripplots $(n=5)$. A statistically significant difference was observed between the groups on days 6 and $10(p<0.05)$, according to the ANOVA statistical analysis and Tukey's post hoc test. 


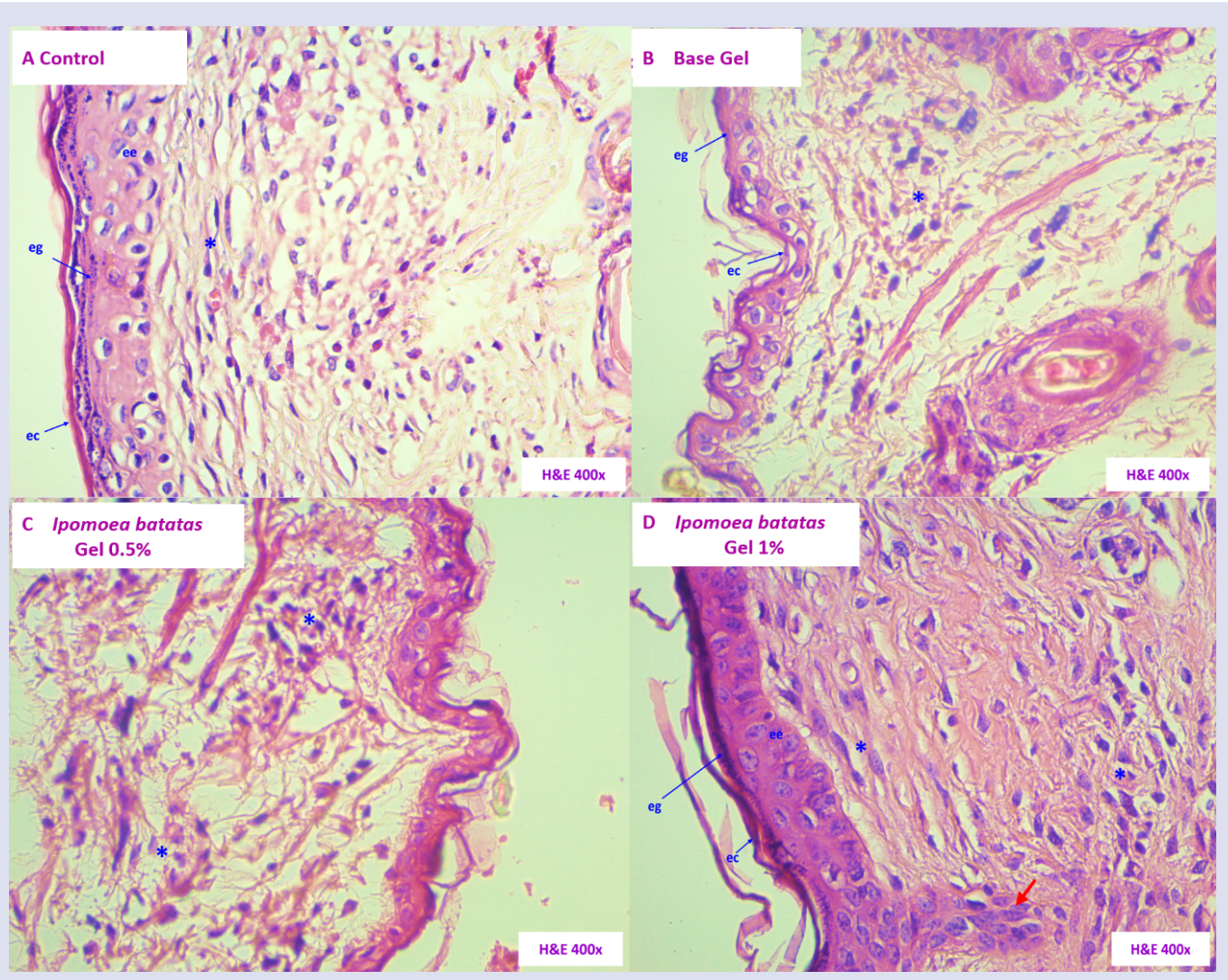

Figure 2: Histopathological sections of the skin of Mus musculus Balb / c. A. Group I (Control). B. Group II. (Base Gel). C. Group III (Gel I. batatas 0.5\%). D. Group IV (Gel I. batatas 1\%). Keratinous stratum corneum (ec), stratum granulosa (eg), stratum spinosum (ee), basal cells (eb) dermal papillae (arrow), fibroblasts (*), sweat glands (gs), eschar (s). (Hematoxylin and Eosin stained, 400X).

The healing activity of Ipomoea batatas peels "purple sweet potato" can be attributed to its phytochemical composition, since its main components include polyphenols, ${ }^{24}$ phenolic acids such as hydroxybenzoic acid, chlorogenic acid, ferulic acid, caffeic acid, gallic acid, ${ }^{25-26}$ flavonoids such as quercetin, myricetin, kaempferol, luteolina, ${ }^{27}$ rutin and catechin, ${ }^{26}$ and anthocyanins with basic cyanidin and peonidin monomers, which are found as cyanidin and peonidin glycosides acylated with caffeic acids, hydroxybenzoic and ferulic..$^{28-30}$ These compounds promote the wound healing process, since they have one or more of the faculties to act as anti-inflammatory, antioxidant or antibacterial compounds, activities necessary to achieve a successful completion in the restoration of the skin. ${ }^{31}$

Among the mechanisms of action of the secondary metabolites reported in Ipomoea batatas and that are related to the healing activity, mention is made of gallic acid, kaempferol, rutin, catechin and quercetin, recognized as powerful anti-inflammatories. These would play a very important role, since their action is associated with blocking neutrophil infiltration, a fact that is related to the reduction of levels of tumor necrosis factor alpha (TNF- $\alpha$ ), interleukin 1 (IL-1 $\beta$ ) and nitric oxide (NO). ${ }^{26}$ This effect can be complemented by the action of anthocyanins, which reduce the excessive expression of inducible nitric oxide synthase, cyclooxygenase- 2 and pro-inflammatory cytokines including TNF- $\alpha$ and IL- $1 \beta,{ }^{32}$ inhibition of activated B-cell kappa light chain enhancer nuclear factor (NF- $\kappa \mathrm{B})$ that promotes the expression of genes related to inflammation. ${ }^{33}$

Appropriate choice of the pharmaceutical form of administration determines the effectiveness of the treatment. Therefore, our results can also be favored by the pharmaceutical form used for the administration of the active principles, in this case gels. Gels have several advantages in promoting wound healing; among them we can mention its ability to provide the humid environment required for healing, in addition to allowing the incorporation of plant extracts. ${ }^{34-36}$

\section{CONCLUSION}

Gel based on the ethanolic extract of the peels of Ipomoea batatas (L.) Lam. demonstrated to accelerate the wound healing process induced in mice, the most effective treatment being the $1 \%$ gel formulation. It is postulated that the healing mechanism of I. batatas is related to phytoconstituents such as anthocyanins and phenolic compounds that exert antioxidant, antimicrobial and anti-inflammatory effects, which contribute to the healing process.

\section{CONFLICTS OF INTEREST}

Authors declare no conflict of interest

\section{ACKNOWLEDGMENT}

This work was financed by CONCYTEC-FONDECYT within the call E041-01 [Contract N 115-2018-FONDECYT-BM-IADT-SE].

\section{CONTRIBUTIONS OF AUTHORS}

CRSC and VEVLT prepared the first draft. CMON and MVGB collected the plant species and entered the herbarium. WASG and JLCR performed the preparation of extracts and topical formulations. AACP and CLAV kept the animals during the research and administered treatments. LMGE and JHV performed the extraction of skin samples. PCV performed the histopathological analyzes and JDC and ADGS performed the statistical analysis and imaging. 


\section{REFERENCES}

1. Lordani TVA, De Lara CE, Ferreira FBP, De Souza Terron Monich M, Da Silva CM, Lordani CRF, et al. Therapeutic effects of medicinal plants on cutaneous wound healing in humans: a systematic review. Mediators Inflamm. 2018;2018.

2. Okur ME, Karantas ID, Şenyiğit Z, Üstündağ Okur N, Siafaka PI. Recent trends on wound management: New therapeutic choices based on polymeric carriers. Asian J Pharm Sci. 2020;15(6):661-84

3. Okur ME, Karadağ AE, Okur NÜ, Özhan Y, Sipahi H, Ayla Ş, et al. In vivo wound healing and in vitro anti-inflammatory activity evaluation of Phlomis russeliana extract gel formulations. Molecules. 2020;25(11):1-17.

4. Weng T, Wu P, Zhang W, Zheng Y, Li Q, Jin R, et al. Regeneration of skin appendages and nerves: Current status and further challenges. J Transl Med. 2020;18(1):1-17.

5. Shedoeva A, Leavesley D, Upton Z, Fan C. Wound healing and the use of medicinal plants. Evidence-based Complement Altern Med. $2019 ; 2019$

6. Stoica AE, Chircov C, Grumezescu AM. Nanomaterials for wound dressings: An Up-to-Date overview. Molecules. 2020;25(11).

7. Wang Z, Fang B, Chen X, Liao M, Chen J, Zhang X, et al. Temporal patterns of gene expression associated with tuberous root formation and development in sweetpotato (/pomoea batatas). BMC Plant Biol. 2015;15(1):1-13.

8. Manolo D, Garcés S, Patricia L, Arcos A, Vinicio L, Aldás P, et al. Efecto de la inclusión de camote morado (/pomoea batata) en la elaboración de mermelada de naranjilla (Solanum quitoense). Agroindustrial Sci. 2018;8(2):153-7.

9. Hu Y, Deng L, Chen J, Zhou S, Liu S, Fu Y, et al. An analytical pipeline to compare and characterise the anthocyanin antioxidant activities of purple sweet potato cultivars. Food Chem. 2016;194:46-54

10. Desnita R, Wahdaningsih S, Hervianti S. Topical Microemulsion's Formulation of Purple Sweet Potato (/pomoea batatas L.) Ethanol Extract as Antioxidant by using Various Concentration of Span 80. Int J PharmTech Res. 2016;9(3):198-203.

11. Frond AD, luhas Cl, Stirbu I, Leopold L, Socaci S, Andreea S, et al. Phytochemical characterization of five edible purple-reddish vegetables: Anthocyanins, flavonoids, and phenolic acid derivatives. Molecules. 2019;24(8).

12. Sun H, Zhang P, Zhu Y, Lou Q, He S. Antioxidant and prebiotic activity of five peonidin-based anthocyanins extracted from purple sweet potato (/pomoea batatas (L.) Lam.). Sci Rep. 2018;8(1):1-12.

13. Ayeleso TB, Ramachela K, Mukwevho E. Aqueous-methanol extracts of orange-fleshed sweet potato (Ipomoea batatas) ameliorate oxidative stress and modulate type 2 diabetes associated genes in insulin resistant C2C12 cells. Molecules. 2018;23(8).

14. Chen H, Sun J, Liu J, Gou Y, Zhang X, Wu X, et al. Structural characterization and anti-inflammatory activity of alkali-soluble polysaccharides from purple sweet potato. Int J Biol Macromol. 2019;131:484-94.

15. Li J, Shi Z, Mi Y. Purple sweet potato color attenuates high fatinduced neuroinflammation in mouse brain by inhibiting mapk and NF-kB activation. Mol Med Rep. 2018;17(3):4823-31.

16. Khoo HE, Azlan A, Tang ST, Lim SM. Anthocyanidins and anthocyanins: Colored pigments as food, pharmaceutical ingredients, and the potential health benefits. Food Nutr Res. 2017;61(1).

17. Hermes D, Dudek DN, Maria MD, Horta LP, Lima EN, De Fátima Â et al. In vivo wound healing and antiulcer properties of white sweet potato (/pomoea batatas). J Adv Res. 2013;4(4):411-5

18. Jiang $P$, Han B, Jiang L, Li Y, Yu Y, Xu H, et al. Anti-Inflammatory and Anticancer Activities of Taiwanese Purple-Fleshed Sweet Potatoes (/pomoea batatas L. Lam ) Extracts. Asian Pac J Trop Biomed. 2015;2015(3):607-18.
19. Sagástegui-Guarniz WA, Silva-Correa CR, Villarreal-La Torre VE, González-Blas MV, Sagástegui-Guarniz WO, Calderón-Peña AA et al. Wound healing by topical application of Momordica charantia L. formulations on mice. Veterinary World. 2021;14(10): 2699-2704.

20. Rosas-Cruz GP, Silva-Correa CR, Calderón-Peña AA, Villarreal-La Torre VE, Aspajo-Villalaz CL, Cruzado-Razco JL, et al. Wound Healing Activity of an Ointment from Solanum tuberosum L. "Tumbay Yellow Potato" on Mus musculus Balb/c. Pharmacogn J. 2020;12(6):1268-75.

21. Hakim RF, Fakhrurrazi, Dinni. Effect of Carica papaya Extract toward Incised Wound Healing Process in Mice (Mus musculus) Clinically and Histologically. Evidence-based Complement Altern Med. 2019;2019.

22. Huang $\mathrm{HC}$, Lin $\mathrm{H}$, Huang MC. Lactoferrin promotes hair growth in mice and increases dermal papilla cell proliferation through Erk/Akt and Wnt signaling pathways. Arch Dermatol Res. 2019;311(5):411-20.

23. Sciences B, Kingdom U, Francisco S. Microenvironmental reprogramming by three- dimensional culture enables dermal papilla cells to induce de novo human hair-follicle growth. 2013;2013.

24. Sun Y, Pan Z, Yang C, Jia Z, Guo X. Comparative assessment of phenolic profiles, cellular antioxidant and antiproliferative activities in ten varieties of sweet potato (/pomoea batatas) storage roots. Molecules. 2019;24(24)

25. Li A, Xiao R, He S, An X, He Y, Wang B, et al. Research Advances of Purple Sweet Potato Anthocyanins: Extraction, Identification, Stability, Bioactivity, Application, and Biotransformation Aoran. Molecules. 2019;

26. Majid M, Nasir B, Zahra SS, Khan MR, Mirza B, Haq I. Ipomoea batatas L. Lam. ameliorates acute and chronic inflammations by suppressing inflammatory mediators, a comprehensive exploration using in vitro and in vivo models. BMC Complement Altern Med. 2018;18(1):1-20.

27. Park SY, Lee SY, Yang JW, Lee JS, Oh SD, Oh S, et al. Comparative analysis of phytochemicals and polar metabolites from colored sweet potato (Ipomoea batatas L.) tubers. Food Sci Biotechnol. 2016;25(1):283-91.

28. Vishnu VR, Renjith RS, Mukherjee A, Anil SR, Sreekumar J, Jyothi AN. Comparative Study on the Chemical Structure and in Vitro Antiproliferative Activity of Anthocyanins in Purple Root Tubers and Leaves of Sweet Potato (/pomoea batatas). J Agric Food Chem. 2019;67(9):2467-75

29. Li GL, Lin Z, Zhang $H$, Liu Z, Xu Y, Xu G, et al. Anthocyanin Accumulation in the Leaves of the Purple Sweet Potato I/pomoea batatas L.) Cultivars. Molecules. 2019;24(20).

30. Palungwachira $\mathrm{P}$, Tancharoen S, Phruksaniyom C, Klungsaeng $S$, Srichan R, Kikuchi $K$, et al. Antioxidant and Anti-Inflammatory Properties of Anthocyanins Extracted from Oryza sativa L. In Primary Dermal Fibroblasts. Oxid Med Cell Longev. 2019;2019.

31. Ibrahim N 'Izzah, Wong SK, Mohamed IN, Mohamed N, Chin KY Ima-Nirwana $S$, et al. Wound healing properties of selected natura products. Int J Environ Res Public Health. 2018;15:2360.

32. Jeong JW, Lee WS, Shin SC, Kim GY, Choi BT, Choi YH. Anthocyanins downregulate lipopolysaccharide-induced inflammatory responses in BV2 microglial cells by suppressing the NF-kB and Akt/MAPKs signaling pathways. Int J Mol Sci. 2013;14(1):1502-15.

33. Xu L, Choi TH, Kim S, Kim SH, Chang HW, Choe M, et al. Anthocyanins from black soybean seed coat enhance wound healing. Ann Plast Surg. 2013;71(4):415-20.

34. Davoodi-Roodbordeii F, Afshar M, Haji Abas Tabrizi F, Choopani S, Torkaman G, Moayer F, et al. Topical hydrogel containing Fumaria vaillantii Loisel. extract enhances wound healing in rats. BMC Complement Altern Med. 2019;19(1):1-9.

35. Lai WF, Rogach AL. Hydrogel-Based Materials for Delivery of Herbal Medicines. ACS Appl Mater Interfaces. 2017;9(13):11309-20.

36. Mohammadinejad R, Maleki $H$, Larrañeta $E$, Fajardo AR, Nik AB, Shavandi A, et al. Status and future scope of plant-based green hydrogels in biomedical engineering. Appl Mater Today. 2019;16:213-46. 


\section{GRAPHICAL ABSTRACT}

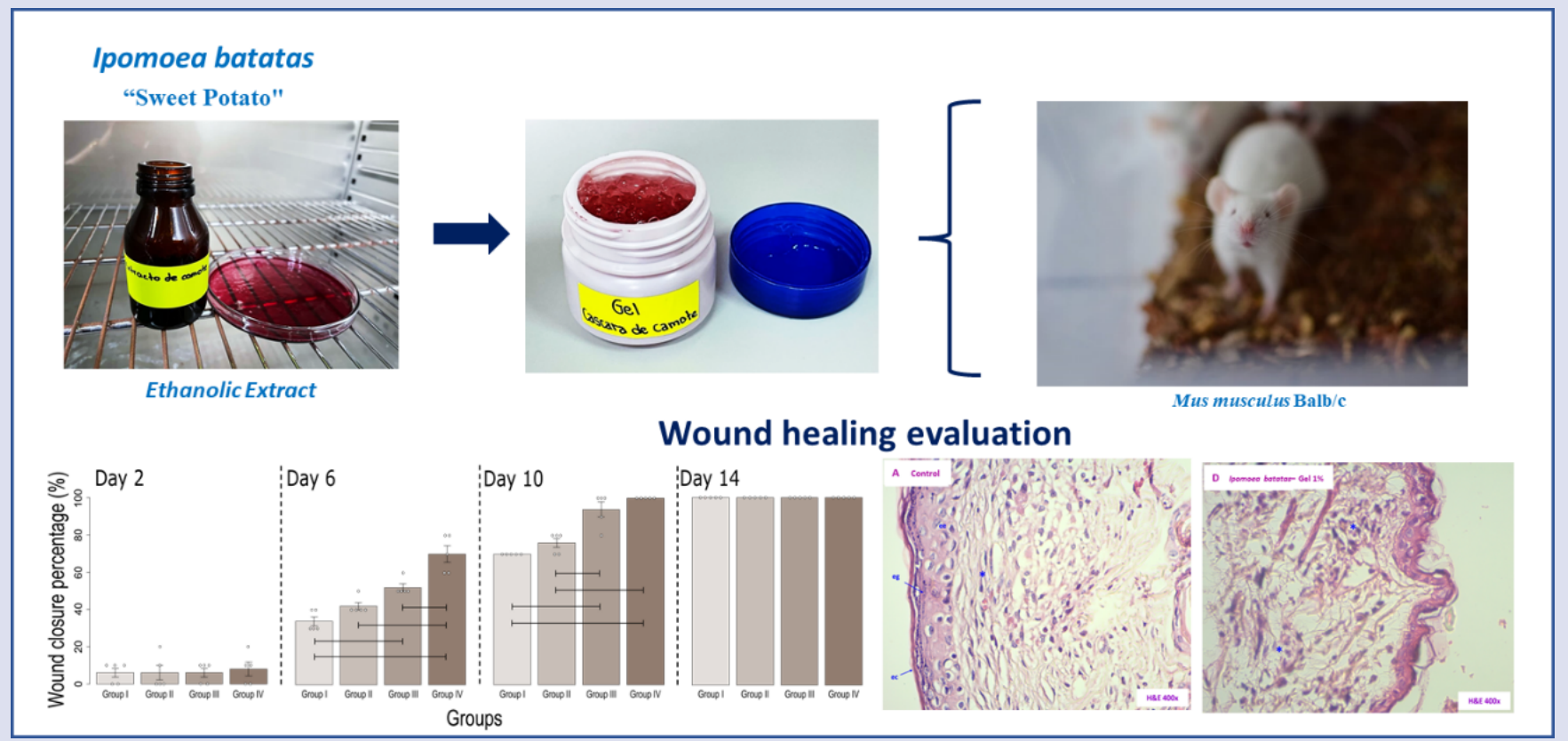

\section{ABOUT AUTHORS}

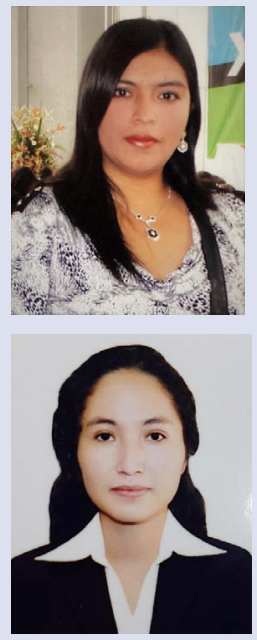

Silva-Correa Carmen R. Department of Pharmacology professor at Universidad Nacional de Trujillo, holds a degree in Pharmacy and Biochemistry (2011), Master of Chemical Sciences (2017), graduate student at Doctoral program in Biomedical Sciences since 2019. Currently participates in research projects on toxicological and pharmacological evaluation of medicinal plants, focusing on the evaluation of the wound healing activity of traditional medicinal plants from Peru.

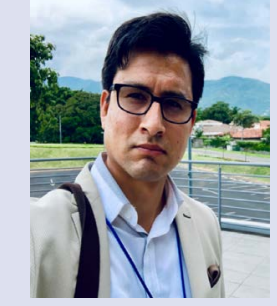

Ortiz-Noriega Cristel M. Graduate in Pharmacy and Biochemistry at the Universidad Nacional de Trujillo. Thesis preparation student on the FONDECYT project agreement N¹15-2018-FONDECYT-BM-IADT-SE.

Villarreal-La Torre Víctor E. Master of Chemical Sciences, holds a degree in Pharmacy from Universidad Nacional de Trujillo (2011). Professor in the Medicinal Chemistry undergraduate program and the Molecular basis of the Action of Xenobiotics postgraduate program at the Universidad Nacional de Trujillo. He currently executes research projects aimed at the discovery of antimicrobial compounds in medicinal plants. Graduate student at Doctoral program in Pharmacy and Biochemistry since 2019. 

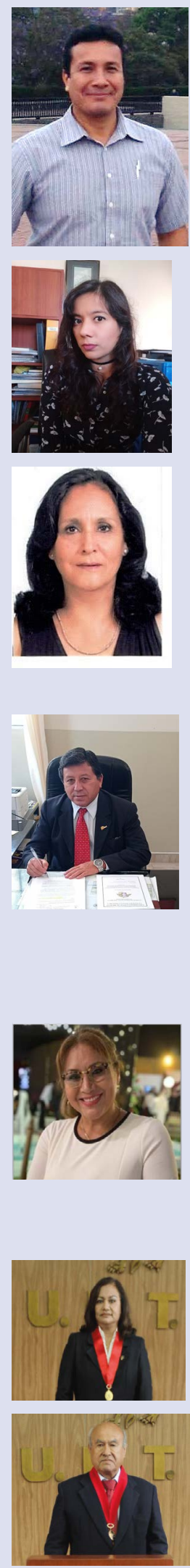

Calderón-Peña Abhel A. Master of Physiology and Biophysic, holds a degree in Biological Science from Universidad Nacional de Trujillo. Animal Physiology, Human Anatomy, Histology and Biochemistry Professor of undergraduate program at the Universidad Nacional de Trujillo. He is currently conducting research on oxidative stress and the discovery of antioxidant compounds in medicinal plants. Graduate student at Doctoral in the Biological Sciences program.

Aspajo-Villalaz Cinthya L. Master of Food Technology holds a degree in Biological Science from Universidad Nacional de Trujillo. Bromatology and Biochemistry Professor of undergraduate program at the Universidad Nacional de Trujillo. She is currently conducting research on microbiological control of pharmaceutical products, functional foods design and evaluation. Graduate student at Doctoral in the Biological Sciences program.

Guerrero-Espino Luz M. Professor. Department of Physiology. School of Medicine - Universidad Nacional de Trujillo, PhD in Biomedical Sciences, Master's Degree in Physiology. Researcher in neuroscience, altitude, and exercise.

Sagástegui-Guarniz William A. Department of Pharmacology professor at Universidad Nacional de Trujillo, Perú since 1993 - to date. Graduated in Pharmacy and Biochemistry at Universidad Nacional de Trujillo. Master's in chemical sciences, 1999. Doctorate in Biomedical Sciences, graduate program of the Universidad Nacional de Trujillo, 2010. Doctorate in Desenvolvimento e Inovação Tecnológica em Medicamentos at Universidade Federal Do Ceará, Brazil, 2020. Currently participates in research projects aimed at the phytochemical characterization of medicinal plants, focusing on antimicrobial activity, resistance to antimicrobials, and antimalarial.

González-Siccha Anabel D. Doctor in Pharmacy and Biochemistry. Master of science in Biochemistry. Magister in Physiology. Pharmacy degree in Spain. Second degree in Clinical and Biological Analysis. Principal Professor of Biochemistry and Molecular Biology undergraduate program of the Department of Biochemistry, Pharmacy and Biochemistry Faculty at the Universidad Nacional de Trujillo. Research Fellow in the Laboratory of Biochemistry and Molecular Biology at the Faculty of Medicine from Albacete, Universidad de Castilla-La Mancha from Spain. Research on Nutritional assessment and anemia in vulnerable populations. Research on medicinal plants on immunomodulatory, antitumor and tumor marker activity. Research on DLK1 and DLK2 proteins and differentiation on mouse tissues through immunohistochemistry.

González-Blas María V. Master of Chemical Sciences holds a degree in Pharmacy and Biochemistry from Universidad Nacional de Trujillo, Doctorate studies in Biomedical Sciences. She has participated in research projects of hypoglycemic, diuretic and antileishmanicidal activity of compounds in medicinal plants.

Cruzado-Razco José L. Department of Pharmacology professor at the Universidad Nacional de Trujillo, holds a degree in Pharmacy and Biochemistry, Master of Physiology and Biophysics, Doctorate studies in Biomedical Sciences. He has participated in research projects on epidemiology of tropical diseases and currently, in research on antimalarial, leishmanicidal and anti-trypanosomal activity of medicinal plants. 

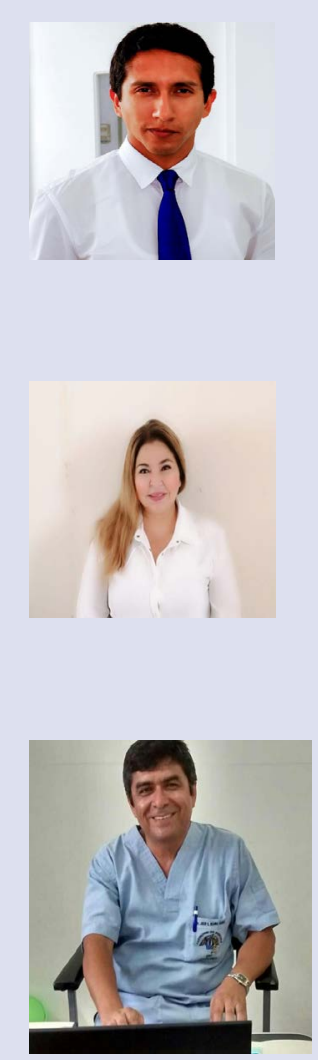

Del Rosario-Chávarri Jorge. Microbiologist, with a Master of Science from the Universidad Nacional de Trujillo (2013). Formulator and researcher in environmental microbiology projects, performing phenotypic and molecular characterization of bacteria with biotechnological applications. Currently a student of the doctoral program in Molecular Genetics and Microbiology at the Pontificia Universidad Católica de Chile.

Contreras-Vera Patricia. Master of Education with a mention in Higher Education Didactics, Medical surgeon graduated from the San Martín de Porres University. Specialist in Pathology of the Academic Program of Second Specialization of Medicine of the National University of Trujillo. PhD candidate in Clinical and Translational Research. Professor of the Chair of Histology at the Antenor Orrego Private University. Currently researcher of the project: Development and production of biocompatible ferroelectric nanocomposites based on Barium titanate with potential applications to the diagnosis of lung cancer and implants that accelerate the osteogenesis process. She also serves as Medical Director at the Northern Genetics and Biology Center GEMA. Medical Manager of the PACVER PATHOLOGY Laboratory and Doctor of the Pathology Service of the Víctor Lazarte Echegaray Hospital of EsSalud.

Hilario-Vargas Julio . Professor. Departamento de Fisiología, Facultad de Medicina. Universidad Nacional de Trujillo. Master in Physiology and Doctor in Biomedical Science. Research and publishes works on pemphigus, evaluation of medicinal plant extracts, and physiological function in special environments.

Cite this article: Silva-Correa CR, Ortiz-Noriega CM, Villarreal-La Torre VE, Calderón-Peña AA, Aspajo-Villalaz CL, Guerrero-Espino LM, et al. Effect of a Gel Based on Ipomoea batatas (Purple Sweet Potato) on Dermal Wound Healing in Mice. Pharmacogn J. $2021 ; 13(6)$ Suppl: 1720-1726. 